\title{
Sexual differences in the role of kainate receptors in controlling gonadotrophin secretion in prepubertal rats
}

\author{
L. Pinilla, M. Tena-Sempere and E. Aguilar* \\ Department of Physiology, Faculty of Medicine, Avda Menendez Pidal s/n, Córdoba University, \\ Córdoba 14004, Spain
}

\begin{abstract}
Glutamate stimulates $\mathrm{LH}$ secretion in adult female rats after activation of $N$-methyl-Daspartic acid (NMDA), kainate, and 2-amino-3-hydroxy-5-methyl-4-isoxazol propionic acid receptors. In contrast to the positive role of kainate receptors in the control of $\mathrm{LH}$ secretion in adult females, neither activation nor antagonization of kainate receptors in immature rats modified the onset of puberty. The present experiments were carried out to establish why, if kainate stimulates LH release in adult rats, it fails to advance puberty in immature rats, and to determine whether the role of kainate receptors is sexually dimorphic around puberty. In Expt 1, 4-, 8-, 12-, 16-, 20- and 30-day-old females were investigated $15 \mathrm{~min}$ after administration of vehicle or kainic acid, a kainate receptor agonist $\left(2.5 \mathrm{mg} \mathrm{kg}^{-1}\right)$. In Expt 2, 30-day-old female rats were studied 2, 5 and $10 \mathrm{~min}$ after administration of vehicle, $2.5 \mathrm{mg}$ kainic acid $\mathrm{kg}^{-1}$ or NMDA, an NMDA receptor agonist (15 $\mathrm{mg} \mathrm{kg}^{-1}$ ). In Expt 3, female and male rats were gonadectomized or sham-gonadectomized on day 23 and investigated on day 30 after injection of vehicle, kainic acid $\left(2.5 \mathrm{mg} \mathrm{kg}^{-1}\right.$ at $\left.-15 \mathrm{~min}\right)$ or 6,7 dinitroquinoxaline-2,3 dione (DNQX), a kainate antagonist $\left(2 \mathrm{mg} \mathrm{kg}^{-1}\right.$ in two injections at -120 and $-60 \mathrm{~min}$ ). Finally, 30-day-old female and male rats were investigated $15 \mathrm{~min}$ after injection of vehicle or NMDA ( $15 \mathrm{mg} \mathrm{kg}^{-1}$ ) or 60 min after administration of different doses of 5-methyl-10,11-dihydro-5H-dibenzo[a,d]cyclohepten-5,10-imine (MK-801), an NMDA antagonist $\left(0.1,0.25\right.$ or $\left.0.50 \mathrm{mg} \mathrm{kg}^{-1}\right)$. The results indicate that the role of kainate receptors in the control of gonadotrophin secretion is sexually dimorphic around puberty, since: (a) LH secretion was stimulated by kainic acid in male rats but inhibited in females; (b) FSH secretion was inhibited by kainic acid in ovariectomized females, but not in orchidectomized males; and (c) DNQX inhibited LH secretion in males but not in females. These differences were specific for kainate receptors since, in both sexes, NMDA stimulated and MK-801 inhibited LH secretion. It may be concluded that the secretion of gonadotrophins is modulated differently by kainate receptors in prepubertal male and female rats.
\end{abstract}

\section{Introduction}

Excitatory amino acids (EAAs) are the major activating neurotransmitters in the brain (van den Pol et al., 1990) and play a crucial role in controlling neuroendocrine function (Brann and Mahesh, 1994). Glutamate or its agonists stimulate GnRH release from hypothalamic fragments (Donoso et al., 1990; Brann and Mahesh, 1991; Arias et al., 1993) and immortalized GnRH neurones (Mahachoklertwattana et al., 1994), as well as LH release in vivo (Urbanski and Ojeda, 1987; Luderer et al., 1993; Brann and Mahesh, 1994). Different glutamate receptor subtypes (Watkins, 1994) mediate glutamate effects on GnRH. Specifically, LH secretion is inhibited in adult female rats after administration of different antagonists of $\mathrm{N}$-methyl-D-aspartic acid (NMDA) (Brann and Mahesh, 1991), kainate (Ping et al.,

\footnotetext{
${ }^{*}$ Correspondence.
}

Received 10 September 1997
1995) and 2-amino-3-hydroxy-5-methyl-4-isoxazol propionic acid (AMPA) receptors (Ping ef al., 1997). LH secretion increases after activation of kainate receptors in adult cyclic female rats (Abbud and Smith, 1991, 1993) and in prepubertal males (Aguilar et al., 1996). However, neither activation nor antagonization of kainate receptors affects onset of puberty in female rats (Brann et al., 1993a), in contrast with the ability of NMDA treatment to induce precocious puberty (MacDonald and Wilkinson, 1990; Urbanski and Ojeda, 1990). Normal onset of puberty in female rats treated with kainate and 6,7 dinitroquinoxaline-2,3 dione (DNQX) (Brann et al., 1993a) could be due to a lack of effect of these drugs on gonadotrophin secretion. The present study was undertaken to evaluate this hypothesis and to analyse whether the role of kainate receptors is sexually dimorphic around puberty by evaluating the effects of kainate, NMDA, DNQX and 5-methyl-10,11dihydro-5H-dibenzo[a,d]cyclohepten-5,10-imine (MK-801) in prepubertal male and female rats. 


\section{Materials and Methods}

Animals and treatments

Prepubertal Wistar rats bred in our laboratory were used. The litter size was adjusted to eight pups per dam on the day of birth (day 1). Animals were weaned at 21 days of age and housed under controlled conditions of temperature $\left(20^{\circ} \mathrm{C}\right)$ and light ( $12 \mathrm{~h}$ light: $12 \mathrm{~h}$ darkness) with free access to pelleted food (Rodent Toxicology Diet; B\&K Universal, Barcelona). Kainic acid and NMDA were obtained from Sigma, Barcelona. The kainate antagonist, DNQX, was obtained from Tocris (Langford, Bristol). The NMDA antagonist, MK-801, was purchased from Research Biochemicals International, Natick, MA. Kainic acid, NMDA and MK-801 were dissolved in saline immediately before use. DNQX was dissolved in $45 \%(\mathrm{w} / \mathrm{v})$ 2 -hydroxypropyl- $\beta$-cyclodextrin. Doses and timings were selected on the basis of previous studies (Ping et al., 1995; Pinilla et al., 1995, 1996a, b; Aguilar et al., 1996, 1997).

\section{Experimental design}

In Expt 1, 4-, 8-, 12-, 16-, 20- and 30-day-old female rats were injected i.p. with vehicle or $2.5 \mathrm{mg}$ kainic acid $\mathrm{kg}^{-1}$ and decapitated $15 \mathrm{~min}$ later. Since only a weak but significant decrease in serum LH concentrations was observed on day 30 , and considering the rapid effect of kainic acid, in a second experiment (Expt 2) 30-day-old females were killed 2, 5 and $10 \mathrm{~min}$ after i.p. injection of vehicle, $2.5 \mathrm{mg}$ kainic acid $\mathrm{kg}^{-1}$ or $15 \mathrm{mg}$ NMDA kg ${ }^{-1}$. NMDA was used as a positive control since it is known to stimulate $\mathrm{LH}$ release (Carbone et al., 1992). In Expt 3, female and male rats were gonadectomized or sham-gonadectomized on day 23 and killed on day 30 after injection of vehicle or $2.5 \mathrm{mg}$ kainic acid $\mathrm{kg}^{-1}$ at $-15 \mathrm{~min}$ or administration of vehicle or $2 \mathrm{mg}$ DNQX kg-1 in two injections at -120 and $-60 \mathrm{~min}$ to evaluate sexual dimorphism in the role of kainate receptors in the control of gonadotrophin secretion. Finally, 30-day-old female and male rats were killed $15 \mathrm{~min}$ after injection of vehicle or $15 \mathrm{mg}$ NMDA kg ${ }^{-1}$ or 60 min after administration of different doses of MK-801 (0.1, 0.25, $0.50 \mathrm{mg} \mathrm{kg}^{-1}$ ) to analyse whether, as reported for kainate, the role of NMDA receptors in the control of gonadotrophin secretion is sexually dimorphic around puberty. In all experiments, trunk blood was collected. After centrifuging at $1650 \mathrm{~g}$ at $4^{\circ} \mathrm{C}$ for $20 \mathrm{~min}$, serum was collected, frozen and stored at $-20^{\circ} \mathrm{C}$ until use.

\section{Hormone determination}

$\mathrm{LH}$ and FSH concentrations were measured in duplicate using a double-antibody radioimmunoassay method and reagents supplied by NIH (Bethesda, MD). Rat-LH I-9 and rat FSH-I-8 were labelled with ${ }^{125} \mathrm{I}$ by the chloramine $\mathrm{T}$ method (Greenwood et al., 1963). Hormone concentrations were expressed as ng serum $\mathrm{ml}^{-1}$ of the reference preparations LH-rat-RP-2 and FSH-rat-RP-3. The intra-assay coefficients of variation were 6 and $7 \%$ for $\mathrm{LH}$ and $\mathrm{FSH}$, respectively.
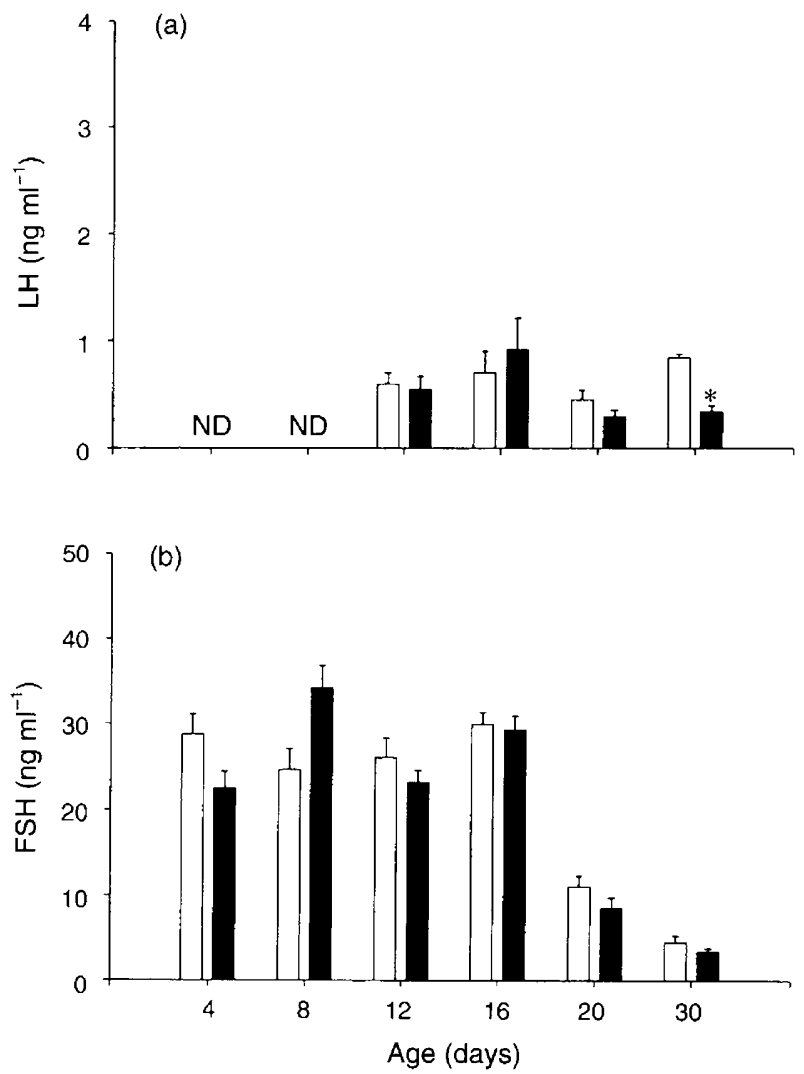

Fig. 1. Serum LH and FSH concentrations at different ages in female prepubertal rats decapitated $15 \mathrm{~min}$ after injection of vehicle ( $\square$ ) or $2.5 \mathrm{mg}$ kainic acid $\mathrm{kg}^{-1}(\boldsymbol{\square})$. Values are given as mean $\pm \operatorname{SEM}(n=10$ animals per group). ${ }^{*} P \leq 0.05$ versus vehicle-injected group (Student's $t$ test). ND: not detectable.

Interassay variabilities were $<12 \%$. Sensitivities were $0.075 \mathrm{ng}$ $\mathrm{ml}^{-1}$ and $0.4 \mathrm{ng} \mathrm{ml}^{-1}$ for $\mathrm{LH}$ and FSH, respectively.

\section{Statistics}

Results are expressed as mean \pm SEM. Since the criteria of homogeneity of variance were not fulfilled in all situations, statistical analyses were performed after logarithmic transformation of data. Differences between experimental groups were subjected to analysis of variance (ANOVA) followed by Tukey's test or by Student's $t$ test.

\section{Results}

Effects of kainic acid on gonadotrophin secretion at different ages in female rats

Serum LH concentrations during the first week of life were below the limits of detection in most animals and increased later (Fig. 1). Administration of kainic acid did not change LH secretion at any age studied, except for a weak inhibition on day 30. Serum FSH concentrations decreased after day 16 and remained unchanged after kainic acid administration. 

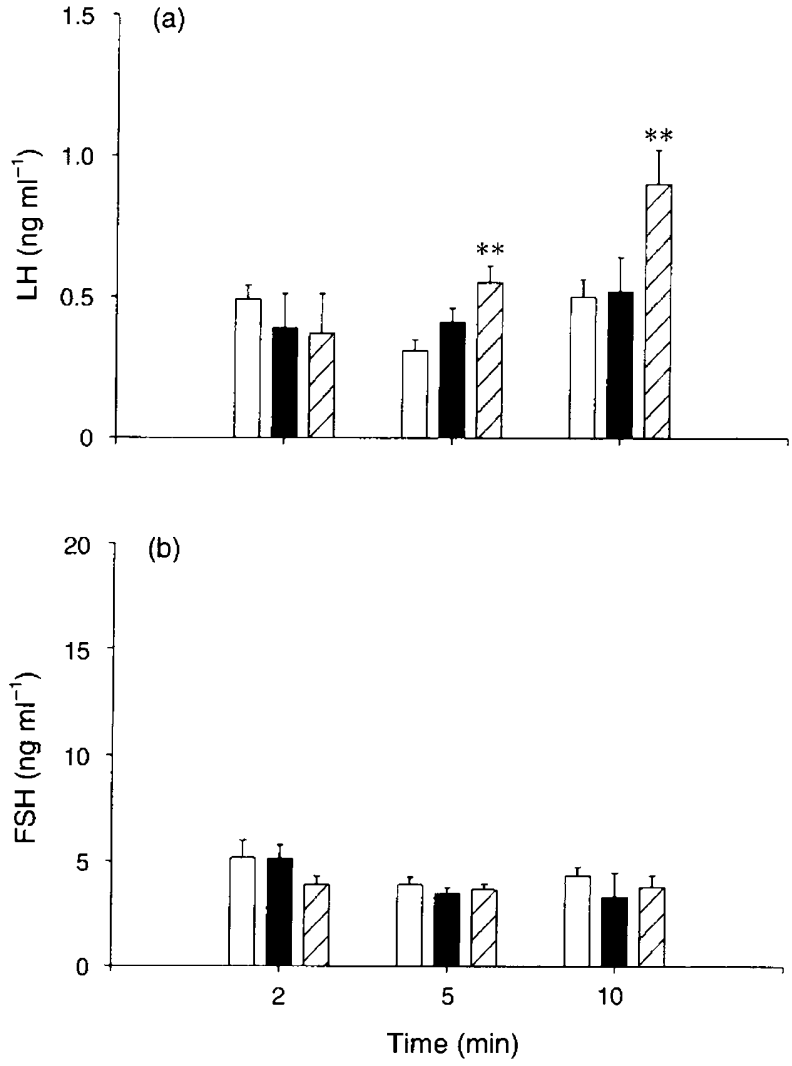

Fig. 2. Serum LH and FSH concentrations in 30-day-old female rats decapitated at different times after injection of vehicle ( $\square$ ), $2.5 \mathrm{mg}$ kainic acid $\mathrm{kg}^{-1}(\boldsymbol{\square})$ or $15 \mathrm{mg} N$-methyl-D-aspartic acid $\mathrm{kg}^{-1}$ (《). Values are given as mean $\pm \operatorname{SEM}(n=10$ animals per group). $* * P \leq 0.01$ versus vehicle-injected group (ANOVA followed by Tukey's test).

Time course of kainic acid and N-methyl-D-aspartic acid actions on gonadotrophin secretion in 30-day-old females

Serum LH concentrations increased significantly 5 and 10 min after administration of NMDA, while changes after treatment with kainic acid were not significant (Fig. 2). Serum FSH concentrations were not significantly affected by administration of NMDA or kainic acid.

\section{Effects of kainic acid and 6,7 dinitroquinoxaline-2,3 dione on gonadotrophin secretion in intact and gonadectomized rats}

Serum LH and FSH concentrations significantly increased I week after ovariectomy. Kainic acid inhibited LH secretion in intact and ovariectomized females and FSH secretion in ovariectomized females. In contrast to this inhibitory effect, kainic acid significantly stimulated LH release in intact male rats (Table 1).

In female rats, serum LH and FSH concentrations remained unchanged after administration of $2 \mathrm{mg} D N Q X \mathrm{~kg}^{-1}$ in two doses at -120 and -60 min. In contrast, DNQX significantly decreased LH secretion in intact and orchidectomized males, while serum FSH concentrations remained unchanged.
Table 1. Serum concentrations of LH and FSH in intact and gonadectomized female and male rats decapitated after treatments with kainic acid or 6,7 dinitroquinoxaline-2,3 dione (DNQX)

\begin{tabular}{|c|c|c|c|}
\hline Group & Treatment & $\begin{array}{c}\mathrm{LH} \\
\left(\mathrm{ng} \mathrm{ml}^{-1}\right)\end{array}$ & $\begin{array}{c}\mathrm{FSH} \\
\left(\mathrm{ng} \mathrm{ml}^{-1}\right)\end{array}$ \\
\hline \multirow[t]{2}{*}{ Intact females } & Vehicle & $0.76 \pm 0.03$ & $4.18 \pm 0.44$ \\
\hline & Kainic acid & $0.44 \pm 0.01^{*}$ & $3.98 \pm 0.39$ \\
\hline \multirow[t]{2}{*}{ Ovariectomized females } & Vehicle & $5.22 \pm 0.38$ & $59.44 \pm 3.02$ \\
\hline & Kainic acid & $2.60 \pm 0.35^{*}$ & $47.40 \pm 1.85^{*}$ \\
\hline \multirow[t]{2}{*}{ Intact females } & Vehicle & $0.56 \pm 0.03$ & $3.98 \pm 0.61$ \\
\hline & DNQX & $0.48 \pm 0.01$ & $4.44 \pm 0.56$ \\
\hline \multirow[t]{2}{*}{ Ovariectomized females } & Vehicle & $6.08 \pm 0.57$ & $51.52 \pm 1.73$ \\
\hline & DNQX & $7.96 \pm 1.53$ & $57.20 \pm 3.43$ \\
\hline \multirow[t]{2}{*}{ Intact males } & Vehicle & $0.45 \pm 0.15$ & $15.86 \pm 1.40$ \\
\hline & Kainic acid & $1.18 \pm 0.08^{* *}$ & $17.45 \pm 1.01$ \\
\hline \multirow[t]{2}{*}{ Intact males } & Vehicle & $0.98 \pm 0.34$ & $19.50 \pm 1.37$ \\
\hline & DNQX & $0.14 \pm 0.09^{* *}$ & $18.13 \pm 1.12$ \\
\hline \multirow[t]{2}{*}{ Orchidectomized males } & Vehicle & $9.03 \pm 1.28$ & $48.57 \pm 3.03$ \\
\hline & DNQX & $4.21 \pm 0.82^{* *}$ & $45.97 \pm 1.90$ \\
\hline
\end{tabular}

Values are given as means \pm SEM of ten animals per group.

Animals were injected with $2.5 \mathrm{mg}$ kainate $\mathrm{kg}^{-1}$ at $-15 \mathrm{~min}$ and with $1 \mathrm{mg}$ DNQX kg ${ }^{-1}$ at -120 and $-60 \mathrm{~min}$.

${ }^{*} P \leq 0.05, \quad{ }^{* *} P \leq 0.01$ versus corresponding vehicle-injected group (ANOVA followed by Tukey's test).

Effects of N-methyl-D-aspartic acid and MK-801 on gonadotrophin secretion in intact rats

Secretion of LH increased significantly in males and females

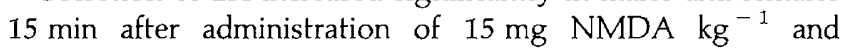
decreased $60 \mathrm{~min}$ after administration of different doses of MK-801 (Fig. 3).

\section{Discussion}

Puberty in female rats is a complex process initiated at the hypothalamus. Prepubertal GnRH neurones have low activity that is enhanced at the end of the juvenile period by an increase in stimulatory inputs (Ojeda and Urbanski, 1994). Some neurotransmitters, such as neuropeptide $Y$, noradrenaline and EAAs, have been implicated in the prepubertal activation of GnRH neurones (Ojeda and Urbanski, 1994). The actions of EAAs are mediated by activation of different postsynaptic receptor subtypes, such as NMDA, kainate and AMPA receptors. Activation of NMDA receptors advances the time of puberty in female rats (Urbanski and Ojeda, 1987; MacDonald and Wilkinson, 1990; Brann et al., 1993a), while administration of antagonists of NMDA receptors, such as MK-801 or DL,2-amino-5-phosphono valeric acid (AP-5), delays vaginal opening and blocks the oestradiol-induced LH surge in prepubertal ovariectomized rats (Urbanski and Ojeda, 1990; Meijs Roelofs et al., 1991). In contrast, the onset of puberty remained unaffected after activation or antagonization of kainate receptors with kainic acid or DNQX, respectively (Brann et al., 1993a). The basis for this finding remains unexplained, since LH and FSH concentrations after treatment with kainic acid or 

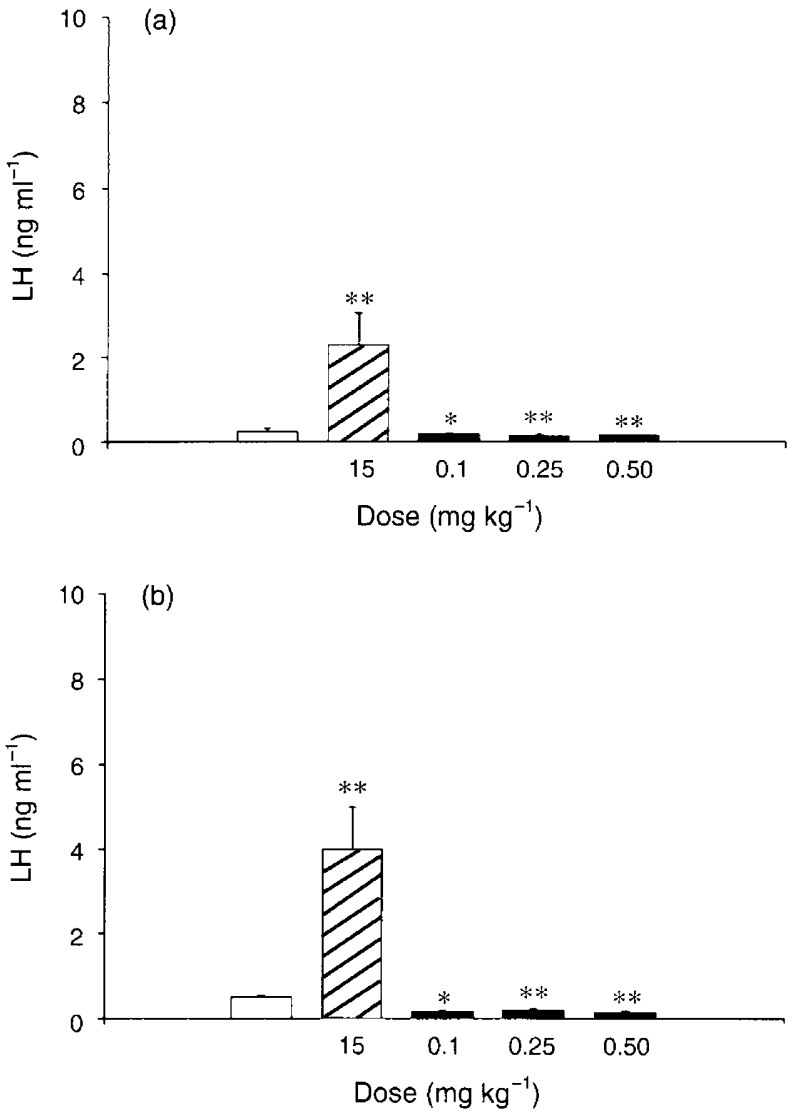

Fig. 3. Serum LH concentrations in 30-day-old (a) female and (b) male rats decapitated $15 \mathrm{~min}$ after injection of $15 \mathrm{mg} \mathrm{N}$-methyl-D-aspartic acid (NMDA) $\mathrm{kg}^{-1}(\square)$ or $60 \mathrm{~min}$ after injection of different doses $\left(0.1,0.25\right.$ and $\left.0.50 \mathrm{mg} \mathrm{kg}^{-1}\right)$ of the NMDA antagonist MK-801 ( $\boldsymbol{\square}$ ). Values from animals decapitated 15 or $60 \mathrm{~min}$ after vehicle injection were similar and were pooled for presentation $(\square)$. Values are given as mean $\pm \operatorname{SEM}$ ( $n=10$ animals per group, except vehicle-injected group which included 20 animals). ${ }^{*} P \leq 0.05,{ }^{*} P \leq 0.01$ versus vehicle-injected group (ANOVA followed by Tukey's test).

DNQX were not measured in these experiments (Brann et al., 1993a).

In adult male and female rats, NMDA and kainic acid stimulate LH secretion (Price et al., 1978; Schainker and Cicero, 1980; Abbud and Smith, 1991; Luderer et al., 1993; Strobl et al, 1993) and the antagonists of NMDA (AP-5, MK-801) and kainate receptors (DNQX) suppress pulsatile $\mathrm{LH}$ secretion in adult male rats (Ping et al., 1995) and ovulatory LH surges in females (López et al., 1990; Brann and Mahesh 1991, 1993b). NMDA increases LH secretion in prepubertal males (Aguilar et al., 1996) and females (Carbone et al., 1992; MacDonald and Wilkinson 1992). Aguilar et al. (1996) showed a clear increase in serum LH concentrations after administration of $2.5 \mathrm{mg}$ kainic acid $\mathrm{kg}^{-1}$ to prepubertal male rats. However, similar studies in prepubertal females have not yet been performed.

The present study was undertaken to analyse changes in $\mathrm{LH}$ and FSH secretion in prepubertal females after activation or antagonization of kainate receptors. Initially, a weak decrease in $\mathrm{LH}$ secretion was observed $15 \mathrm{~min}$ after administration of kainic acid in 30 day-old females. In the later experiments, this inhibitory action was observed in intact and ovariectomized females. Furthermore, kainic acid was also able to reduce FSH secretion in ovariectomized female rats. Since the effects of EAAs appear to be mediated through changes in the release of GnRH (Gay and Plant, 1987; Bourguignon et al., 1989; Donoso et al., 1990; Strobl et al., 1993), the findings of the present study point to an inhibition of GnRH secretion after activation of kainate receptors.

The effects of DNQX, a potent kainate receptor antagonist, on gonadotrophin secretion were analysed to evaluate whether kainate receptors are activated tonically in prepubertal female rats. Serum LH and FSH concentrations remained unchanged after administration of DNQX to intact and ovariectomized females, suggesting that gonadotrophin secretion, both in basal conditions and after ovariectomy, is not modulated by kainate receptors. On the contrary, the decrease in LH concentrations after administration of MK-801 points to a physiological role of NMDA receptors in the control of $\mathrm{LH}$ release in prepubertal female rats. Taken as a whole, the results of the present study suggest that the role of kainate receptors in the control of gonadotrophins during puberty in females is not as important as that of NMDA receptors. This finding may explain why the onset of puberty in female rats was not affected by administration of kainic acid or DNQX (Brann and Mahesh, I993a).

At present, it is not clear why kainate does not stimulate $\mathrm{LH}$ in prepubertal female rats, while doing so in adult females. The ability of AMPA and NMDA receptor agonists to stimulate $\mathrm{LH}$ release was found to require a background of oestrogen (Brann and Mahesh, 1992; Ping et al., 1997). It is possible that the kainate receptors involved in the regulation of $\mathrm{LH}$ release were upregulated by oestrogens and remained ineffective before puberty, when oestradiol concentrations were low. Alternatively, it is possible that, before puberty, kainate stimulates the secretion of an LH release-inhibiting factor of hypothalamic origin (Hwan and Freeman, 1987).

The inability of manipulations (activation or antagonization) of kainate receptors to modify gonadotrophin secretion in prepubertal females, where only a minor inhibitory effect of kainic acid on LH secretion was observed, is in marked contrast to data obtained for prepubertal males, in which kainic acid elicited LH release (Aguilar et al., 1996). This finding suggests that the role of kainate receptors in the neuronal circuitry governing GnRH release is sexually dimorphic, at least before puberty. This dimorphism seems to be restricted to the involvement of kainate receptors in the control of GnRH secretion, since kainic acid stimulated $\mathrm{GH}$ release in both prepubertal male and female rats (Tena-Sempere et al., 1995) and inhibited prolactin release in both sexes (Pinilla et al., 1996a, b).

In conclusion, the results of the present study indicate that the role of kainate receptors in the control of gonadotrophin secretion in prepubertal rats is sexually dimorphic, being stimulatory only in males. Data obtained also suggest that, unlike NMDA receptors, kainate receptors play only a minor role in the control of gonadotrophin secretion in prepubertal female rats.

This work was supported by grant PM95-0112 (DGICYT.Spain). The authors gratefully acknowledge the NIDDK (Bethesda, MD) for supplying materials for $\mathrm{LH}$ and FSH radioimmunoassays. They are 
indebted to M. Sullivan for assistance in the revision of the manuscript and to F. Jimenez for technical help.

\section{References}

Abbud R and Smith S (1991) Differences in the luteinizing hormone and prolactin responses to multiple injections of kainate as compared to $N$-methyl-D.L-aspartate, in cycling rats Endocrinology 129 3254-3258

Abbud R and Smith S (1993) Altered luteinizing hormone and prolactin responses to excitatory amino acids during lactation Neuroendocrinology $\mathbf{5 8}$ $454-464$

Aguilar E, Tena-Sempere M, Gonzalez D and Pinilla L (1996) Control of gonadotropin secretion in prepubertal male rats by excitatory amino acids Andrologia 28 163-169

Aguilar E, Tena-Sempere M, Aguilar R, Gonzalez D and Pinilla L (1997) Interactions between $N$-methyl-D-aspartate, nitric oxide and serotonin in the control of prolactin secretion in prepubertal male rats European Journal of Endocrinology $13799-106$

Arias P, Jarry H, Leonhardt S, Moguilevski J and Wuttke W (1993) Estradiol modulates the LH release response to $\mathrm{N}$-methyl-D-aspartate in adult female rats: studies on hypothalamic luteinizing hormone-releasing hormone and neurotransmitter release Neuroendocrinology 57 710-715

Brann DW and Mahesh VB (1991) Endogenous excitatory amino acid involvement in the preovulatory and steroid-induced surge of gonadotropins in the female rat Endocrinology 128 1541-1547

Brann DW and Mahesh VB (1992) Excitatory amino acid regulation of gonadotropin secretion: modulation by steroid hormones Journal of Steroid Biochemistry and Molecular Biology 41 847-850

Brann DW and Mahesh VV (1994) Excitatory amino acids: function and significance in reproduction and neuroendocrine regulation Frontiers in Neuroendocrinology $153-49$

Brann DW, Zamorano PL, Ping L and Mahesh VB (1993a) Role of excitatory amino acid neurotransmission during puberty in female rat Molecular and Cellular Neuroscience 4 107-112

Brann DW, Ping L and Mahesh VB (1993b) Role of non-NMDA receptor neurotransmission in steroid and preovulatory gonadotropin surge expression in the female rat Molecular and Cellular Neurosciences 4 292-297

Bourguignon J, Gerard A, Mathieu J, Simons J and Franchimont P (1989) Pulsatile release of gonadotropin-releasing hormone from hypothalamic explants is restrained by blockade of $N$-methyl-D,L-aspartate receptors Endocrinology 125 1090-1096

Carbone S, Szwarcfarb B, Losada M and Moguilevski J (1992) Effects of ovarian steroids on the gonadotropin response to $N$-methyl-D-aspartate and on the hypothalamic excitatory amino acid levels during sexual maturation in female rats Endocrinology 130 1365-1370

Donoso AO, López F and Negro-Vilar A (1990) Glutamate receptors of the non- $N$-methyl-D-aspartic acid type mediate the increase in luteinizing hormone-releasing hormone release by excitatory amino acids Endocrinology $126414-420$

Gay VL and Plant TM (1987) N-methyl-D,L-aspartate elicits hypothalamic gonadotropin-releasing hormone release in prepubertal male rhesus monkeys Endocrinology 120 2289-2296

Greenwood FC, Hunter WM and Glover JS (1963) The preparation of ${ }^{1.31} \mathrm{I}-$ labelled human growth hormone of high specific radioactivity Biochemistry Journal 89 114-123

Hwan JC and Freeman ME (1987) A physiological role for luteinizing hormonerelease inhibiting factor of hypothalamic origin Endocrinology 121 1099-1103

López F, Donoso A and Negro-Vilar A (1990) Endogenous excitatory amino acid neurotransmission regulates the estradiol-induced LH surge in ovariectomized rats Endocrinology 126 1771-1773
Luderer U, Strobl FJ, Levine JE and Schwartz NB (1993) Differential gonadotropin responses to $\mathrm{N}$-methyl-D,L-aspartate in metestrous, proestrus and ovariectomized rats Biology of Reproduction 48 857-866

MacDonald MC and Wilkinson M (1990) Peripubertal treatment with N-methyl D-aspartic acid or neonatally with monosodium glutamate accelerates sexual maturation in female rats, an effect reversed by MK801 Neuroendocrinology $52 \quad 143-149$

MacDonald MC and Wilkinson M (1992) Characterization and ontogenesis of $\mathrm{N}$-methyl-D-aspartate-evoked luteinizing hormone secretion in immature female rats Journal of Neuroendocrinology 4 223-229

Mahachoklertwattana P, Black SM, Kaplan SL, Bristow JD and Grumbach M (1994) Nitric oxide synthesized by gonadotropin-releasing hormone neurones is a mediator of $\mathrm{N}$-methyl-D-aspartate (NMDA)-induced $\mathrm{GnRH}$ secretion Endocrinology 135 1709-1712

Meijs-Roelofs HMA, Kramer P and van Leeuwen ECM (1991) The N-methyl-Daspartate receptor antagonist MK-80I delays the onset of puberty and may acutely block the first spontaneous LH surge and ovulation in the rat Journal of Endocrinology 131 435-441

Ojeda SR and Urbanski HF (1994) Puberty in the rat. In The Physiology of Reproduction 2nd Edn pp 363-409. Eds E Knobil and JD Neill. Raven Press, New York

Ping L, Mahesh VB and Brann DW (1995) Effect of NMDA and non-NMDA receptor antagonists on pulsatile luteinizing hormone secretion in the adult male rat Neuroendocrinology $61 \quad 226-2.34$

Ping L, Mahesh VB, Bhat GK and Brann DW (1997) Regulation of gonadotropinreleasing hormone and luteinizing hormone secretion by AMPA receptors Neuroendocrinology 66 24-253

Pinilla L, Tena-Sempere M and Aguilar E (1995) The role of excitatory amino acid pathways in the control of pituitary function in neonatally oestrogenized male rats Journal of Endocrinology 147 51-57

Pinilla L, Gonzalez D, Tena-Sempere M, Aguilar R and Aguilar E (1996a) Mechanisms of inhibitory action of kainic acid on prolactin secretion in male rats Journal of Endocrinology 151 159-167

Pinilla L, Gonzalez D, Tena-Sempere M, Aguilar R and Aguilar E (1996b) Effects of $N$-methyl-D-aspartate and kainic acid on prolactin secretion in prepubertal female rats European Journal of Endocrinology 135 464-468

Price MT, Olney JW and Cicero TJ (1978) Acute elevations of serum luteinizing hormone induced by kainic acid, $N$-methyl-aspartic acid or homocysteic acid Neuroendocrinology 26 352-358

Schainker BA and Cicero TJ (1980) Acute central stimulation of luteinizing hormone by parenterally administered $N$-methyl-D,L-aspartic acid in the male rat Brain Research 184 425-437

Strobl FJ, Luderer U, Besecke L, Wolfe A, Schwartz NB and Levine JE (1993) Differential gonadotropin responses to $N$-methyl-D,L-aspartate in intact and castrated male rats Biology of Reproduction 48 867-873

Tena-Sempere M, Pinilla L and Aguilar $\mathbf{E}$ (1995) A possible role for endogenous nitric oxide $(\mathrm{NO})$ in kainic acid $(\mathrm{KA})$-induced growth hormone $(\mathrm{GH})$ release in prepubertal rats Neuroendocrinology Letters 4 251-257

Urbanski HF and Ojeda SR (1987) Activation of luteinizing hormone-releasing hormone release advances the onset of female puberty Neuroendocrinology 46 $273-276$

Urbanski HF and Ojeda SR (1990) A role for $N$-methyl-D-aspartate (NMDA) receptors in the control of LH secretion and initiation of female puberty Endocrinology 126 1774-1776

Van den Pol A, Waurin J and Dudek F (1990) Glutamate, the dominant excitatory transmitter in neuroendocrine regulation Science 250 I276-1278

Watkins JC (1994) The NMDA receptor content: origins and development. In The NMDA Receptor pp 1-30 Eds GL Collinbridge and JC Watkins. Oxford University Press, Oxford 